UDC 327:330.34(510:497.11)

$339.92(510: 497.11)$

DOI: https://doi.org/10.18485/iipe_ria.2020.71.1180.3

Biblid 0543-3657, 71 (2020)

Vol. LXXI, No. 1180, pp. 45-71

Review paper

\title{
THE RESULTS AND RISKS OF CHINA'S BELT AND ROAD INVESTMENT PROJECTS IN SERBIA
}

\author{
Katarina ZAKIĆ ${ }^{1}$
}

\begin{abstract}
China has been steadily increasing the level of its investment projects in Serbia since 2010. With Serbia joining its two very important initiatives, the $17+1$ and the Belt and Road, those investments have grown exponentially. The projects vary in size and are placed in different sectors, with infrastructure projects as leading ones.

The main purpose of this paper is to analyse the achieved results of Chinese investment projects in Serbia connected to the Belt and Road Initiative from the economic point of view. At the same time, the author will present the list of potential risks for Serbia arising from those projects. The analysed data span from 2014 to May 2020, and they were collected from various sources and evaluated with content analysis. The risks were analysed by applying a scenario method. From an empirical standpoint, this paper will give a new perspective on the risks that Serbia is facing concerning the BRI projects, in the light of changes in the domestic and international environment, especially due to the impact of the COVID-19 pandemic.
\end{abstract}

The author concludes that the BRI projects in Serbia contribute to the Serbian economic development, but at the same time, Serbia is facing two major risks loan repayment and failure to comply with ecological standards.

Keywords: Serbia, China, Belt and Road Initiative, investment projects, economic results, risk.

\footnotetext{
${ }^{1}$ Katarina Zakić, Research Fellow, Institute of International Politics and Economics, Belgrade. E-mail: katarina@diplomacy.bg.ac.rs

The paper presents the findings of a study developed as a part of the research project entitled 'Serbia and challenges in international relations in 2020', financed by the Ministry of Education, Science, and Technological Development of the Republic of Serbia, and conducted by the Institute of International Politics and Economics, Belgrade.
} 


\section{INTRODUCTION}

China and Serbia (previously as a part of former Yugoslavia) have had good diplomatic relations for decades, but they have not always been followed by developed economic relations. The turning point in economic cooperation happened in 2009 when China signed with Serbia the Agreement on Comprehensive Strategic Partnership. ${ }^{2}$ At the meeting of the presidents, several political and economic projects were negotiated.

One of the first projects agreed upon was the construction of the first Chinese bridge in Europe across the river Danube. The China Road and Bridge Company Corporation started to build this bridge in 2010 in Belgrade, and the construction was finished in 2014. The Mihajlo Pupin Bridge was officially opened during the Third Prime Ministers' meeting of 16+1 Cooperation Mechanism in Belgrade.

A strategic partnership was an introduction to the further development of cooperation between the two countries. In 2012, Serbia was among the first countries that agreed to join a new Cooperation Mechanism called 16+1. With this platform, China was pursuing a new way of cooperation with 16 countries situated in Central and Eastern Europe. ${ }^{3}$ Before the $16+1$ was established, the then Chinese Prime Minister Wen Jiabao said that the main reason for founding this mechanism was to "strengthen coordination and cooperation and deliver tangible results through cooperation to the benefit of people in China and Central and Eastern Europe." (Ministry of Foreign Affairs of the Republic of China, 2012) In 2019, Greece joined this initiative, and from that point, the official name of this initiative is $17+1$.

In addition, Serbia is also a member of the Belt and Road Initiative (BRI), proposed by the Chinese President Xi Jinping in late 2013. The initiative aspires to connect China with countries that are part of the Economic Belt (the continental part - Asia and Europe) and the Maritime Road (the maritime part - Asia, Africa, and Europe). The main aim is to mobilize resources that could improve connectivity between the BRI countries by building roads, railroads, ports, and different infrastructural projects. China provides financing for those projects through the Silk Road Fund and the Asia Infrastructural Investment Bank as the main financial institutions.

\footnotetext{
${ }^{2}$ For detailed information about the development of relations between China and Serbia see: Lađevac, I. (April 2020). The Republic of Serbia and the Belt and Road Initiative. In A. Jović Lazić, A. Troude (Eds.), Security challenges and the place of the Balkans and Serbia in a changing world (pp. 273- 283), Belgrade, Serbia: Institute of International Politics and Economics.

${ }^{3}$ Albania, Bulgaria, Bosnia and Herzegovina, Croatia, the Czech Republic, Estonia, Hungary, Lithuania, Latvia, Montenegro, North Macedonia, Poland, Romania, Serbia, Slovenia, and Slovakia.
} 
The cooperation platform $17+1$ is nowadays integrated into the BRI, with a note that most of the Chinese projects in Serbia started through the 16+1 since Serbia joined this initiative first. Serbia and China have negotiated different projects through two initiatives, and many of them are now at some stage of realization. The first projects in which Serbia and China collaborated were in the field of infrastructure, then followed two acquisitions (production and mine), and in the end, the first greenfield investment in production.

Beside Greece, Serbia is one of the countries in the Balkans that have signed the biggest number of projects and it is the second in the volume of Chinese investments (Zakić, Radišić, 2019b, p. 64). A lot of questions about this cooperation have been raised. Among them, two are important for this paper: 1 . is this cooperation beneficial for Serbia, and 2. what are the risks that Serbia is facing by implementing the BRI investment projects. For this purpose, the conducted analysis consists of the presentation of the completed and ongoing Chinese investment projects in Serbia.

All the projects will be analysed and evaluated individually in terms of their history, the project phase, invested funds, and effects on the Serbian economy. In addition, for each project, existing and potential risks will be explored using scenario methods.

\section{LITERATURE REVIEW ON THE BRI INVESTMENT PROJECTS IN SERBIA}

Chinese economic presence in Europe has attracted a lot of attention, especially in regards to the $17+1$ and the BRI, which consequently entailed numerous research articles and books assessing the Chinese impact on European development. The findings of the authors who wrote about Serbian cooperation with China will be in focus.

Ladevac, in the article dedicated to the development of Serbian cooperation with China, states that Serbia and China linkage is based on mutual understanding and respect but, at the same time, it has never been conditioned. (Lađevac, 2020, p. 273). Jojić mostly shares those views and further states that Serbia and China's cooperation is focused on political and economic interests, and that allows Serbia to solve some burning issues in the economy, which have been slowing down Serbian development for many years. (Jojić, 2017, p. 11) Šekarić, while analyzing geo-economic and geopolitical relations of the Western Balkan countries with China, states that Serbia, among other countries, uses economic cooperation with China to catch up with the EU. (Šekarić, 2020, p. 363) She clarifies that countries in the Western Balkans that are not EU members and that want to become one must improve their economic performances to join the EU. By increasing their 
trade and infrastructural projects with China, they are finding a quick solution to that problem.

Summing the economic results of the BRI in Balkan countries, Zakic and Radišic have explored the impact of the BRI on China's cooperation with those countries (2019a), as well as the prevailing type and sector of the BRI investments. (2019b). The authors conclude that the BRI had a significant impact on the rise of Chinese investment projects in Europe and the Balkans and that China invests resources in traditional sectors and in the form of loans. (Zakić, Radišić, 2019b, p. 65)

Several authors have discussed threats and opportunities arising from Serbia's cooperation with China, and they have different attitudes depending on their viewpoints. For example, Liu and Hurley et al. analyse risk from the Chinese point of view. While Hurley et al. (2018, p. 139) suggest how China can improve its credit policy and save both sides from risk, Liu identifies concrete risk factors China faces in Europe. Among the risks, he points out that logistic chains, differences in infrastructure, institutional rules and regulations, and political turbulences are things that China needs to take into account when deciding on the BRI projects in Europe. (Liu, 2019, p. 61- 64).

Pavlićević identified an opportunity/threat paradigm that can be applied to Sino-Serbian relations. The main threats in this paradigm are following: loans are debt traps; poor governance and outcomes of the project; Chinese projects feed corruption; Chinese projects affect trade imbalance; win-lose relationship; China is seeking influence in the form of economic engagement; forced alignment with China's policies and preferences; jeopardizing Serbia's integration with the EU; erosion of European values; return to the neoliberal political and economic model. (Pavlićević, 2019, p. 697) Obradović (2018), in his analyses of opportunities and challenges of Sino-Serbian cooperation, agrees that some main challenges in Serbian cooperation with China are the EU procedures and standards.

Loans for infrastructure in the CEEC, which are realized by Chinese companies and workforce, with violation of the EU standards, and high public debt are some of the problems identified by Tončev in his analysis of ChinaCEEC cooperation. (Tončev, 2017)

The specific risk analysis of the BRI infrastructural projects in Serbia conducted by Andrić et al. applies content analysis to identify risks in that field. The authors classify the risks into three groups, such as the OBOR policy, construction market, and project. The results show that the key risks in the OBOR highway projects in Serbia are cultural differences, language barrier, safety measures on the site, inflation and currency exchange, soil and water pollution, majeure force, poor quality of materials, unforeseeable ground conditions, noise pollution, and different religious backgrounds. (Andrić et al., p.8) 
Finally, in the research conducted by Hurley et al. (2019), the authors conclude that the risks of repaying Chinese loans exist, and that is inversely proportional to the size of an economy. The authors conclude that after analysing 68 countries that received China's BRI loans, only eight out of 68 are at such risk (Hurley et al., p. 4), and those are small economies that undertook large infrastructural projects. (Stanojević, 2017, p.71).

\section{RESEARCH METHODOLOGY}

The Belt and Road Initiative, as it was stated earlier, integrated the platform $16+1$ into its framework after it was established in late 2013. This is the reason the research period in this paper includes projects that were negotiated through the 16+1 and started in 2014. The final period for this analysis is May 2020, and one of the main reasons why it stopped there is the pandemic of COVID 19 and a temporary halt in negotiations and realization of international projects. The last news about a new agreement with China the Serbian Government released in January 2020.

The projects will be analysed in terms of the type of investments (acquisition, greenfield, joint-venture, loan), the sector in which they are placed (transport, energy, metallurgy, auto industry), and the value of investments. For some projects, it was possible to present background history, which was used in the analysis to assess objectively the achieved results and potential risks of those projects.

The analysis of many articles, briefings, official data, and news reports was used to present the results of China's investment projects in Serbia, as well as to assess the risks that Serbia is facing in that regard. ${ }^{4}$ The results will show if those projects are beneficial for Serbia's economy and its development, while the risk analysis will show existing and potential problems.

Project success will be assessed based on the conditions or business results in the given areas, sectors or companies before and after Chinese investments. If it is not possible to make such a comparison due to the nature of a project, or its current phase, some likely benefits of the project will be presented. Benefit, in those cases, means that their effect on Serbia's economic development in a broader sense is considered through the growth of GDP, employment rate, export, development of transportation or energy sector, etc.

\footnotetext{
${ }^{4}$ Note: In those cases in which state, province, or city Government officials did not issue contracts publicly, news reports were used. If that was the case, the author did try to find reports or speeches that Government officials gave to reporters.

In addition, many reports made by non-governmental organizations were used, which they realised online.
} 
Economic risk as a term has a variety of definitions. One of them states that economic risk presents different macroeconomic conditions (conditions in the whole economy) that may affect an investment or a company's prospects at home or abroad (MBN). There are different methods to analyse economic risks, such as risk matrix, sensitivity analysis, break-even analysis, scenario analysis, etc. Since this paper incorporates diversified projects, the scenario analysis was used as the main method as it was the most appropriate one. Huss states that: "A scenario is a narrative description of a consistent set of factors which define in a probabilistic sense alternative sets of future business conditions." (Huss, 1988) In regards to this analysis, it means that through all publicly available data, all factors relevant to each project are presented and discussed, and all existing or possible risks identified.

\section{RESEARCH RESULTS}

In the following Table 1, Chinese investment projects in Serbia negotiated under the $17+1$ and the BRI are presented. The table consists of eight projects in total, out of which transportation, energy, metallurgy, and auto industry sectors each have two projects. ${ }^{5}$ Two companies, Mei Ta (China-French capital) and Shandong Linglong are private companies, while all the rest of them are Chinese state companies.

Further on, each project will be analysed individually and, in the end, the summary analysis will be presented.

\footnotetext{
${ }^{5}$ Due to limited space in this paper, some Chinese projects were omitted in this analysis such as bypass road around Belgrade and Huawei 5G network.
} 
Table 1 - Chinese investment projects in Serbia (January 2014 - May 2020)

\begin{tabular}{|c|c|c|c|c|c|}
\hline Project & $\begin{array}{l}\text { Chinese } \\
\text { partner/ } \\
\text { investor }\end{array}$ & $\begin{array}{c}\text { Type of the } \\
\text { project }\end{array}$ & Sector & $\begin{array}{c}\text { Status } \\
\text { (finished, } \\
\text { in progress) }\end{array}$ & Value \\
\hline $\begin{array}{l}\text { High speed } \\
\text { railway Belgrade- } \\
\text { Stara Pazova and } \\
\text { Novi Sad - } \\
\text { Subotica }\end{array}$ & $\begin{array}{l}\text { China } \\
\text { Communication } \\
\text { Construction } \\
\text { Company and } \\
\text { China Railway } \\
\text { International }\end{array}$ & loan & transport & in progress & $\begin{array}{l}\$ 1.412 \\
\text { billion }\end{array}$ \\
\hline $\begin{array}{l}\text { Kostolac thermal } \\
\text { power plant }\end{array}$ & $\begin{array}{l}\text { China } \\
\text { Machinery } \\
\text { Engineering } \\
\text { Corporation }\end{array}$ & loan & energy & in progress & $\$ 715.6$ million \\
\hline $\begin{array}{l}\text { Highway } \\
\text { Miloš Veliki } \\
\text { (Corridor 11) }\end{array}$ & $\begin{array}{l}\text { Shandong Hi- } \\
\text { Speed Group } \\
\text { and China } \\
\text { Communication } \\
\text { Construction } \\
\text { Company }\end{array}$ & loan & transport & in progress & $\begin{array}{l}\$ 1.054,3 \\
\text { million }\end{array}$ \\
\hline $\begin{array}{l}\text { Hesteel } \\
\text { Smederevo }\end{array}$ & $\begin{array}{l}\text { HBIS Group } \\
\text { Iron and Steel }\end{array}$ & acquisition & metallurgy & finished & $€ 300$ million \\
\hline Mei Ta & Mei Ta & $\begin{array}{l}\text { joint venture } \\
\text { with Serbian } \\
\text { Government }\end{array}$ & $\begin{array}{l}\text { auto } \\
\text { industry }\end{array}$ & finished & $\$ 97$ million \\
\hline Zijin Mining Bor & Zijin Mining & acquisition & metallurgy & finished & $\begin{array}{l}\$ 1.26 \text { billion } \\
\text { and } \$ 200 \\
\text { million for } \\
\text { previous loans }\end{array}$ \\
\hline $\begin{array}{l}\text { Shandong } \\
\text { Linglong tire } \\
\text { company }\end{array}$ & $\begin{array}{l}\text { Shandong } \\
\text { Linglong }\end{array}$ & greenfield & $\begin{array}{l}\text { auto } \\
\text { industry }\end{array}$ & in progress & $€ 800$ million \\
\hline $\begin{array}{l}\text { Heating pipeline } \\
\text { between } \\
\text { Obrenovac and } \\
\text { Novi Beograd }\end{array}$ & $\begin{array}{l}\text { Power } \\
\text { Construction } \\
\text { Corporation of } \\
\text { China }\end{array}$ & loan & $\begin{array}{l}\text { hydro and } \\
\text { coal }\end{array}$ & in progress & $\$ 193$ million \\
\hline
\end{tabular}

Source: Author's data collection 


\section{A) High speed railway Belgrade - Stara Pazova and Novi Sad - Subotica}

A high-speed railway between Belgrade and Budapest was the first infrastructural project that was signed under the $16+1$ platform for Serbia. For many decades, the Serbian railways deteriorated slowly, entailing different economic problems. Unfortunately, Serbia did not have the funds to change that situation in previous years. Therefore, when China formed the 16+1, Serbia used this opportunity to nominate this project and start the modernization and construction of one part of its railroads.

Serbia and Hungary negotiated the project conditions with China on several occasions. The plan was to use loans from the Chinese state bank and hire Chinese companies and workforce for the entire railway from Belgrade to Budapest. That plan was changed because the procedures upon which the three sides agreed were not in line with the EU regulations for building infrastructural projects. The EU members must obey procedures that guarantee a public tender, in which different companies can publicly apply for a job. China wanted to avoid this procedure and make a bilateral arrangement with both countries, which in the case of Hungary was not possible, and the EU strongly objected. Serbia, on the other hand, as a non-EU member, but a country that is in the process of joining the EU could use different procedures. The EU was not comfortable with this decision, but Serbia, nevertheless, continued with this project.

One of the things that affected the beginning of this project in Hungary was the official bidding offer from China for the Hungarian part of the railway. The Hungarian Government, after two public tenders, did not accept the Chinese offers because they were, according to their calculations, more expensive than it was projected (Rencz, 2019, p.8). Finally, after many negotiations, in April 2020, the Hungarian Government signed a deal with China to build its part of the railway, and the value of this part of the project is $\$ 1.855$ billion. (Than, Komuves, $2020)^{6}$ While $15 \%$ is provided by the Hungarian Government, the remaining part will be financed by the China Exim Bank.

Serbia changed its plans several times, and in the end, in 2019, it finally formulated the plan for this project. The novelty of the final decision was that Russia was also included in this project. The Chinese companies will build two parts of the railway: from Belgrade to Stara Pazova and from Novi Sad to Subotica. The first section is $30 \mathrm{~km}$ long, and China Communications Construction Company is in charge of this part of the railway, which is worth $\$$ 350 million. China Railway International and China Communications

\footnotetext{
${ }^{6}$ Note: The Value of the project is stated according to Reuters, but in different sources, we can find different values. The problem with this value is that the Hungarian Government decided that information about this deal is classified, so we cannot be sure if this is the final value.
} 
Construction Company will build the section Novi Sad - Subotica, which is $109 \mathrm{~km}$ long and costs $\$ 1.162$ million. The third part of the railway, which is between these two, is given to the Russian RŽD International Company. The value of that section is $\$ 585$ million, and it is financed by a Russian loan. (Ministarstvo građevinarstva, saobraćaja i infrastructure, 2019)

Serbia's main interest is to integrate its railroad network into the system of the European railroad networks. On the one hand, Serbia needs to make a railway connection between Belgrade and Niš, and after that with North Macedonia and Greece, especially in regards to the Piraeus port. On the other hand, the Hungarian railway needs to be more integrated with the CEEC network so that the railway that Serbia is currently constructing has a purpose. (Rogers, 2019, p.12) If the Serbian part of the railway is used only to meet domestic needs, then the project will neither achieve full productivity nor will it generate enough profit to repay the loans that Serbia used for the construction. The costs of this railway are already high, and if the costs of a future railway from Belgrade to Niš are added, we will see that Serbia needs to use the railway at full capacity in order to justify this project.

\section{B) Kostolac Thermal Power Plant - China Machinery Engineering Corporation}

The Thermal power plant Kostolac is the second biggest one in Serbia after TPP Nikola Tesla and is currently producing 17 percent of EPS [Electric Power Industry of Serbia] electricity generation. The capacity of its Blocks A and B is 750MW, and the last constructed block was commissioned in 1991. (Elektroprivreda Srbije)

The construction of the new Kostolac B3 unit (350 MW) is the first large thermal capacity that the Electric Power Industry of Serbia (EPS) is building after almost three decades. According to official statements, EPS will thus get a modern, efficient unit that will meet all domestic and European environmental criteria, and it will contribute to a long-term safety increase of the Serbian power system. (Energy Strategy of Republic of Serbia)

China Machinery Engineering Corporation (CMEC) is in charge of works in Kostolac TPP. EPS provides 15 percent of funds for the project, while the remaining part is financed by the China Exim Bank loan. EPS will invest 613 million US $\$$ for the construction of the new unit, and together with the increase of the mine Drmno's capacity, the investment will amount to 715.6 million dollars. The Export-Import Bank of China will provide $80 \%$ of the funding for the entire project of $\$ 715$ million through a 20 -year loan (7 years of a grace period and an interest rate of 2.5\%). (Energy Strategy of Republic of Serbia) 
The expected annual production amounts to about 2.5 billion kilowatt-hours of electricity.

It should be noted that the signing of a contract with CMEC on 20 November 2013 was done without a public tender, and the Serbian Government declared that it was legitimately conducted according to the national law since Serbia is still a non-EU country. (CEE Bankwatch Network)

Domestic companies are engaged in construction works as well, and that is beneficial to Serbia. All necessary permits for the construction of the new unit have been obtained, including the Environmental Impact Assessment Study for which Romania gave its consent, but after numerous problems. (RS Ministry of Environmental Protection, 2017)

This is an important strategic project for EPS and the Serbian economy because the last thermal power plant was built almost 27 years ago. The construction of the Kostolac B3 unit is expected to be completed in 2020, and it will increase the total EPS production capacities by about five percent. The new unit will stabilize the production and provide a new modernized system of electricity production. Since the Serbian Government is responsible for repaying the loan, the main risk is the financial one. So far, the Governments have paid new loans and interest rates on time, but the economic situation was stable, and the world was not exposed to a pandemic. It is understandable to question now if Serbia will have enough funds to return loans under new circumstances.

Serbia is following the EU construction standards while building Kostolac B3, and at the same time, it is cooperating with the Chinese company that has not performed the same job under the EU rules. This is the reason why Serbia has hired supervisors to provide that the job is done according to the EU regulations. So, the risk of construction that is not in line with the domestic and EU standards has been avoided, thanks to supervisors.

Serbia heavily relies on lignite for electricity production. Almost $70 \%$ of domestic electricity is produced in that way, and that is a challenge for multiple reasons. The problem lies in the fact that Serbia wants to become an EU member, and the EU has a strict energy policy oriented towards a low-carbon economy. Being in the process of joining the EU, Serbia is obliged to lower the level of electricity produced in this way, and not to increase TPP capacities.

The second challenge relates to environmental issues that occurred during the floods in May and July 2014, which showed to which extent TPP and the Drmno mine are endangered, since Drmno was completely flooded for several months. The mine, which produces ore for Kostolac, currently supplies TPP with around 9 million tons of lignite per year, and it needs to expand its capacities to 12 million in order to feed the new plant. That significant increase will have long-term ecological consequences, and the mine will be more subject to weather conditions. 
The biggest risk that this project is facing is related to ecological standards, especially air pollution. The Centre for Ecology and Sustainable Development (CEKOR) and CEE Bankwatch Network submitted a formal complaint to the Energy Community Treaty Secretariat in September 2018, stating that Serbia did not make an environmental impact assessment for the enlargement of the Drmno mine. (CEE Bankwatch Network, 2018) The pollution of air is significant, and it affects a lot the life of people who live nearby. Serbia needs to pay more attention to ecological standards, developing in a more beneficial way for its citizens.

\section{C) Highway Miloš Veliki E-763 (Corridor XI)}

The Belgrade-South Adriatic E-763 is a branch of the Trans-European Highway, which connects its main route from Gdansk to Athens and Istanbul with the Adriatic Sea and Port of Bar. The E-763 highway will connect Serbia and Montenegro, namely Belgrade and the southern Adriatic, and in a wider context, it will connect Romania, Serbia, Montenegro, and Italy. This road route on Serbian territory is important because it positions Serbia on the international corridor network. Infrastructural projects strongly impact economic development through increased production and distribution of products and services, as well as the living conditions of countries' citizens. (Šaranović et al., 2019, pp. 127)

The section of the highway that goes through Serbia will connect the cities of Belgrade, Obrenovac, Lajkovac, Ljig, Gornji Milanovac, Preljina, Čačak, and Požega. A general contractor for one part of Corridor 11 is Shandong HighSpeed Group, with a contract value for two sections of $\$ 333.3$ million (road Obrenovac - Ub and Lajkovac - Ljig). (Ministry of CTI, Republic of Serbia, 2018) China Communications Construction Company Ltd. is in charge of several parts of Corridor 11 (Novi Beograd - Surčin, Surčin - Obrenovac, and Preljina - Požega), and the total contract value is $\$ 721$ million. (Ministry of CTI, Republic of Serbia, 2019) 85\% will be funded by a loan from the Chinese Export-Import Bank (Exim Bank), and 15\% will be secured from the budget of the Republic of Serbia.

The last section of Corridor 11 is the section from Požega to Boljare (107 $\mathrm{km}$ ), and that is the most difficult one in terms of geological composition and topography. Based on the General Project prepared by CIP, the section is supposed to feature 51 tunnels, 100 bridges, and around 20 overpasses and underpasses. The value of the investment is approximately $€ 1.8$ billion. This section of Corridor 11 will connect Belgrade with Montenegro, and China Road and Bridge Corporation (CRBC) will build this part of the highway. 
For the Serbian Government, the biggest risk is repaying the loans. This highway is very expensive due to the difficult terrain and expected duration of its construction. The main obstacle is to achieve an optimal amount of infrastructural investment and be able to repay them. (Šaranović et al., 2019, pp. 127) So the main thing will be to see if Serbia, similar to the railroads, can finish these roads and repay the loans in pandemic conditions.

It should be noted that once again, there were no public tenders for those infrastructural projects, and that is not a good thing since Serbia wants to join the EU where public procurement is obligatory. Since CRBC publicly won the tender in Croatia for building the Pelješac Bridge and won it against two strong EU companies (Rogelja, Tsimonis, 2020, p. 115), it would be very wise to have public tenders in the future. That will probably overcome the stereotype of Chinese investments in Serbia.

\section{D) HBIS GROUP Serbia Iron \& Steel - Železara Smederevo}

Company SARTID (later named Železara Smederevo) was founded in 1913, and its main purpose is steel production. From 1945 until 1992, the steel plant was governed by the Government of the Socialist Federal Republic of Yugoslavia. It worked constantly, even though the results were not great. During the 1990s, the company's value declined significantly, mainly due to the sanctions against Serbia and Montenegro. The loss of the market and suppliers led to its bankruptcy later.

In April 2003, American steel company U.S. Steel (USS) acquired the bankrupted company for $\$ 23$ million. (BETA, 2003) U.S. Steel promised to put an additional $\$ 150$ million in the plant modernization. This company was the biggest Serbian exporter during the period from 2003 to 2012, and for many years, contributed to the increase of Serbian GDP. On January 31, 2012, U.S. Steel sold the company to the Government of Serbia for $\$ 1$, leaving it with 5,400 employees and amounted liabilities due to reduced global steel prices.

With the departure of US Steel, the company faced many problems. By the end of June 2012, it shut down both of its two large furnaces, while the remaining 5,000 workers were sent on a paid leave. In April 2013, it started operating again with reduced capacity. Ever since then, the Government of Serbia has tried to find a strategic partner. However, several public tenders failed due to a lack of valid bids.

In April 2016, Hesteel Group acquired the business for $€ 46$ million. The Government officials stated that HBIS was going to invest $\$ 300$ million over 2 years in the plant, including the installation of galvanization equipment, and raise production from 0.875 million to 2.1 million tons. (Ministarstvo privrede, 2016) 
The opportunity for HBIS was, of course, the export of steel in Europe, and that was their ultimate goal. Serbia is located conveniently for exporting steel products not just in Europe, but also in Africa or the Middle East, especially in those countries in which Turkey is not so popular and does not export its steel.

The situation in Železara was difficult when HBIS bought it. Despite this, the results from the end of 2018 and the beginning of 2019 indicated that Hesteel became the number one exporter in Serbia (SEEbiz /Tanjug, 2019) due to the many changes that were made in the production process and management of the company.

The biggest problem for both HBIS and Serbia is nowadays caused by the European Commission, which has imposed a cap on steel imports from HBIS. The EC placed Serbia in the group of countries such as Turkey, Moldavia, and Ukraine, whose steel export to the EU market is restricted. This means that all the countries outside the EU were allowed to export 3.3 million tons of hotrolled steel to the EU (starting from the beginning of February until the end of June 2019), and with each additional ton were required to pay the additional 25\% of customs duty. ${ }^{7}$ On the other two steel products from Smederevo an additional customs duty was imposed, and consequently, HBIS had to downsize its production significantly.

Besides this, HBIS is facing, as well as some other Chinese steel companies, accusations of dumping prices of steel. There were several reports, especially by the European Steel Association (Eurofer), against Chinese exporters of steel. (Baláž, Bayer, 2018, p. 120) According to them, HBIS, among others, sells on the EU market certain types of steel imported from China, and they suspect that steel is produced supported by a subsidy. This is the case of dumping prices, and the EU is addressing this issue now.

Negotiations between Belgrade and Brussels are still ongoing about the imposed quotas. The main argument for revising the current quotas is that Brussels used the average production in Smederevo in three years (years 2015, 2016, and 2017) for calculating the limit. The year 2015 is problematic because that was the year in which production was very low. The negotiation process is focused on changing the calculation - so the idea is to use the year 2018 instead of 2015 to calculate three-year average production and adjust the imposed limit for export to the EU. (Obradović, 2019) Although in July 2019, the EU granted

\footnotetext{
${ }^{7}$ Note: For HBIS group: 56.480 tons of hot rolled steel starting from the beginning of February until the end of June 2019; from 1st July 2019 until 30th June 2020 HBIS can export 145.275 tons; from 1st of July 2020 until 30 June 2021152.539 tons. After the 1st of July 2021, the EU will make a final decision about the import of steel from each country in the world individually. (http://rs.n1info.com/Biznis/a454004/EU-ustanovila-kvote-za-uvoz-celika.html)
} 
a 5\% increase for export to all non-EU countries, and in June 2020, they allowed $5 \%$ more, Serbia is still negotiating with the EU to be completely excluded from these quotas.

The second potential risk is associated with the steel price fluctuation on the world market. Unfortunately, that is a serious threat that nobody can anticipate with certainty. The former US partner withdrew from Železara Smederevo (among other things) because the price of steel sharply fell on the world market.

Along with this risk, nowadays, companies are facing an additional risk caused by the pandemic of COVID 19. It was announced in July 2020 that production in Smederevo would be partially closed due to decreased demand for steel on the EU market. Since we stated that HBIS is the biggest exporter from Serbia, this risk is the most serious one.

First, the downsizing of production and export means that the Serbian Government will collect less tax money for its budget. In addition, it means that HBIS will not improve and modernize production capacities. Secondly, the number of workers in the factory could be laid off because of that, and that means more unemployed people. And in the end, the biggest risk, of course, is possible termination of the business contract with HBIS group, because that happened with the previous partner US Steel, which left Serbia with a huge debt and almost 5,000 (un)employed people that were receiving an aid from the Government for 3 years.

The fourth risk, worth mentioning, is related to ecology and sustainable development. HBIS Smederevo is located on the shore of the river Danube and situated very close to the local village. After the acquisition of the steel factory, officials from HBIS Group said that they would pay attention to air and river pollution and that they would invest in more environmental-friendly operations.

However, air pollution is increasing and the number of complaints, not only about usual red dust but pure black dust found in houses and yards, is rising. It should be noted that people who live in the close neighbourhood of the company bought the land and houses under favourable conditions because of its position. Nevertheless, something needs to be done to reduce the level of air pollution.

Hesteel Smederevo is an important factory for this city, and probably around 15,000 citizens of Smederevo live on income coming from the steel factory. It is important, therefore, that the citizens and the factory management, along with local officials and the Serbian Government, find a common solution for everyone.

In the end, it is also worth mentioning the risk concerning cultural differences between Chinese management and Serbian workers. A potential risk of cultural miscommunication can be avoided with good leadership. There were complaints about the management style of Chinese managers in Smederevo. The Chinese managers do need to make an effort to get to know local workers more and to 
adapt to the local culture to yield better effects. And vice versa, they need to educate the workers about their culture and management style so that workers can adapt more successfully to the Chinese way of running the business.

\section{E) Mei Ta}

Mei Ta factory in Obrenovac was opened in 2016, two years after the initial agreement. According to its official website, this factory produces the automotive and engine parts. Even though Serbian officials stated that the factory in Serbia was established with Chinese and French capital, there was no information about that on the company's website. What was possible to find online, was that Mei Ta Ltd. is a company officially registered in Taiwan and that it has several manufacturing facilities in China, India, France, Germany, and Slovakia. (LEI.Info; Janković, Popović, Mitić)

Serbia has a national economic strategy to attract FDI, and due to this decision, many foreign companies have received a different type of state help. Mei Ta in Obrenovac was among them. Serbia agreed to give 14ha of land, as well as to forgive three years of taxes, in exchange for opening a factory and employing around 770 people. (Ministarstvo privrede, Ugovor o dodeli sredstava Mei Ta)

The total value of Chinese investment is $\$ 97$ million, and the Serbian part is around $\$ 20$ million. So far, Mei Ta has opened two factories and employed more than 3,000 people.

The main issue identified in previous years is the location of the factory and a possible risk regarding ecological standards. The factory is situated near the river Sava and the large city water utility (Baric). One of the main things that this factory uses in its production is mechanical oil, which is toxic, and its inappropriate use can damage the environment. (Prodanović, Milivojević, 2017) So far, no complaints in that respect have been officially made, but the potential risk should be identified.

\section{F) Zijin Mining Bor - RTB Bor (Copper Miner and Smelter)}

RTB Bor was originally founded in 1904 by a French bank. The original name of the company was the "French Society of the Bor Mines, the Concession St. George" and its headquarters were in Paris. The French capital remained in Bor until the end of World War II, and in 1951, the company's assets were nationalized by the Government of Yugoslavia. Since then, the company Bor has been in state ownership and performed good results. 
Since the mid-1990s and during the time of sanctions on Yugoslavia, the production in the RTB Bor dropped significantly in comparison to the level of production in the 1970s and 1980s. There were two main reasons for that: the reserves of copper were diminishing and the use of outdated equipment that was not suitable for the production of high-quality ore.

From 2007 until 2017, RTB Bor had three failed privatization tenders: 1. Romanian Cuprom, $\$ 400$ million (BETA, 2007); 2. Austrian A-TEC, $\$ 466$ million, plus an obligation to invest $\$ 180.4$ million in facilities (BETA, 2008), and 3. Russian SMR, $\$ 370$ million, plus $\$ 462$ million for modernization. (B92, Tanjug, 2008)

During those difficult years, RTB Bor made huge debts, which accumulated to 1 billion euros. The Serbian Government attempted to solve some of the issues by financing the cost of new production facilities and writing off the company's debts towards Serbian public companies, worth 1 billion euros.

Even though copper prices started to rise globally and many things within this company were improved, financial losses continued. In 2015 and 2016, the losses were $€ 110$ million and $€ 42$ million, respectively. In 2017 , before the acquisition by ZMG, the mine had a positive result after many years, with $\$ 303$ million ( $€ 255$ million) of revenues and $\$ 73$ million ( $€ 61$ million) of EBITDA. ${ }^{8}$ (Agencija za privredne registre, 2018)

In 2017, the Government of Serbia signed a memorandum with the International Monetary Fund (IMF) in which it stated that they would find a strategic partner or a buyer until March 2018. Due to some difficulties, the sale was postponed until June 2018. Three companies - Zijin Mining from China, Diamond Fields International from Canada, and U Gold from Russia - applied to become a strategic partner of RTB Bor. The Serbian Government accepted the bid by the Chinese Zijin Mining Group.

The Chinese company Zijin Mining took over 63\% of company shares in August 2018. The total value of this investment is $\$ 1.26$ billion. (IIPE, 2018) ZMG obliged to invest an additional 200 US $\$$ million to settle a part of RTB Bor's debt and promised to keep all 5,000 workers. Out of the $\$ 1.26$ billion, 135 million were allocated to tackle the environmental issues and 320 million for opening a new copper mine.

Soon after the news of the acquisition was official, ZMG announced that it bought Nevsun Resources Ltd, a Canadian company, for 1.41 billion US\$. (Zijin Mining, 2019) That news is important, not only to Canada but to Serbia as well. Nevsun is a company that acquired a permit from the Serbian Government in 2010 to explore the site Bor - Metovnica, during which they discovered that

\footnotetext{
${ }^{8}$ EBITDA - Cash flow from operations before tax and financing costs
} 
Cukaru Peki is the site that has a large reserve of copper worth around 100 billion US\$.

By buying RTB Bor and Nevsun, ZMG acquired large amounts of world copper reserves, and it gained a competitive advantage. Therefore, although the Bor mine had many problems, ZMG made a great decision. In the current world order, it is very difficult to achieve a competitive advantage, but in this case, that was gained through the acquisition of resources. In addition, the position of Bor is very good, so the transport costs will be reasonable. Copper will be exported mainly to the EU (Croatia, Germany, and Bulgaria), Turkey, and China. Besides copper, the Bor mine exports silver, palladium, and platinum to Great Britain, sulphuric acid to the Balkan countries, and selenium and pumice stone to Poland. We can see that the export is diversified, and that is always a good thing for reducing risk.

Current results show that the Chinese management along with the Serbian workforce are achieving great results. The results during the last year were 50\% higher compared to the time when the Serbian management was running the company. Furthermore, Zijin employed new 474 workers, and in 2019, the number of work injuries fell by 55\%. (SEEbiz / Tanjug, 2020)

A potential risk for the Serbian Government could be an unsuccessful acquisition of RTB Bor, like the one we had with US Steel. Of course, that could affect budget results and lead to different economic problems.

The second risk may come from the reduction in the number of people who work in the mine. This mine is located in the eastern part of Serbia in which the unemployment rate is around $16 \%$, while in the rest of the country is around $11 \%$. The Serbian economy needs to downscale the unemployment rate so it could prompt up its development.

As the mine is very significant for this region, if this company grows, it will help the development of some other businesses and industries. If not, it will threaten regional economic growth.

In the end, potential problems regarding the emission of sulphur dioxide $\left(\mathrm{SO}_{2}\right)$ are solved to a certain extent, but that can be improved in the future by using modernized eco-friendly technology. ZMG agreed to invest in environmental issues, and there are a couple of them in Bor, which should be solved as soon as possible.

A possible risk for Serbia is the restrictions regarding the export of copper to the EU. The risk is marginally plausible because the level of production of the selected metals that ZMG produces is not high in the EU, but the risk exists due to the EU governing policy to stop Chinese investments in the EU. 


\section{G) Heating pipeline between Obrenovac and Novi Beograd}

The idea of building a heating pipeline between two parts of Belgrade (Novi Beograd and Obrenovac) is not new. Actually, the city of Belgrade started the implementation of this project during the 1990s. The Thermal power plant Nikola Tesla (TENT) situated in Obrenovac produces heated water as a byproduct. Because of that, the city of Belgrade planned to build a heat pipeline that would transport this water to the heating utility in New Belgrade, so that it can be used for heating some parts of Belgrade. The project started, and a significant amount of resource was spent on making and installing the pipelines. During the 1990s, the construction was stopped due to the shortage of finance. In 2001, the city council decided to abandon this project, and for 15 years, the idea was put on hold.

In 2017, at one of the 17+1 meetings, the Serbian Government started to negotiate the completion of this project with China and, in January 2020, the city of Belgrade made a deal with Power China to build the heating pipeline. The project value is $\$ 193$ million, and it will be financed by public utility company Beogradske Elektrane 9 (15\%) and by the Serbian Government (85\%). (Službeni list grada Beograda 68/2020)

The main benefits of this project are: the level of pollution in New Belgrade will be less, hot water from Obrenovac will be used productively and will not be thrown away, and the costs of producing heat in Beogradske Elektrane (BE) will be lower.

Certainly, there is always a question regarding the cost-benefit analysis of this project. There are different opinions about the real benefit of building the heat pipeline. According to some sources, the reduction of electricity production in Obrenovac will be significant, and they will have huge losses, even though BE will cover their losses arising from the reduction in electricity production. (Vlaović, 2019) However, official statements tell a different story. According to them, the total savings that will be achieved by downsizing the import of natural gas for BE, are worth $€ 16$ million, and a part of those savings will be transferred to TENT. (eKapija, 2019)

In addition, it should be taken into account that TENT needs to modify significantly its plant (reconstruction of blocs A3, A4, A5, and A6) to transfer the heated water through that pipeline, and those costs are worth around $€ 20$ million. (Vlaović, 2019)

\footnotetext{
${ }^{9}$ Heating public company
} 


\section{H) Shandong Linglong tire company}

Shandong Linglong Tire Company is one of the leading Chinese companies in this industry, and it is ranked among the top 20 tire manufactures in the world. (Linglong tire) The company has four finished facilities and one under construction in China, as well as one in Thailand. The new production factory in Serbia will be their first one in Europe. Officials from Shandong Linglong stated that they were looking for some time for a country in Europe where they could build a tire factory. Serbia was not on their list whilst Poland, Slovakia, and the Czech Republic were. In the end, the conditions that Serbia offered to this company prevailed to build the factory in Zrenjanin city, situated $70 \mathrm{~km}$ north of Belgrade.

In March 2019, the foundation stone was laid in the industrial zone of Zrenjanin. It was announced that the total value of this project was worth around $€ 800$ mil and that it would be one of the biggest greenfield investments in Serbia. (RAS, 2019) The company would employ around 1,200 workers.

The Chinese company was granted with 96ha of land by Zrenjanin city authorities, which is worth around $€ 8$ million. $(021,2019)^{10}$ According to the plans, the factory was expected to start working in 2021. Before the corona pandemic started in Serbia in March 2020, there were no visible activities on the Linglong construction site. On the other hand, in the local newspaper, we saw that the company started recruiting people in the administration. Those activities are indicative that Linglong is in the beginning stage of starting up its business.

Since Linglong planned to use Chinese construction companies and the workforce for the factory in Zrenjanin, it is obvious that due to the pandemic and travelling restrictions, those plans have to be postponed.

It is also apparent that if this company builds the factory and starts working in Serbia, it will be a huge benefit for the domestic economy. Serbia will increase its export and GDP, downsize the number of unemployed people, receive income from taxes, and raise the standard of people in Vojvodina province.

Several possible risks should be discussed. The first one refers to ecology, or more precisely, air pollution. There are different types of technologies used in tire production. Depending on the type of used technology, the level of air pollution differs. At the moment, there is no official information on the type of production technology that Linglong will use, so we cannot be sure if the local citizens will be exposed to air pollution or not. (Balkan Green Energy News, 2020) Since the future factory will be surrounded by land used for growing crops,

${ }^{10}$ Unlike some others, the contract was not published publicly. 
it is also important from that standpoint to have a clear perspective about the technology that will be used here.

One of the problems that should be considered regarding the work of this factory is the construction of regional roads. (VOICE, 2019) The Serbian Government promised to build roads before this factory starts to work because the existing infrastructure is not suitable for the level of transport that this factory needs. To fulfil this promise the Government needs to purchase private land so it can start with the construction of roads. This is still in the early stage. Only after this phase is over the construction of roads can start.

Even though the factory does not exist, there is a risk connected to the global pandemic, and that can affect the plans of the Chinese investor. Due to recent events, the demand for cars dropped down severely ${ }^{11}$, and consequently, the demand for tires fell, so it is reasonable to ask: will this company start working in Serbia during the unprecedented crisis? Moreover, if Linglong decides to invest, will it invest the promised value or less?

\section{DISCUSSION}

Having analysed all the projects, it is important to discuss the research questions. The first one was dedicated to Serbia and China's cooperation and its results. Having in mind all the projects presented here, the author believes that those projects are beneficial for Serbia and that the two countries have fruitful cooperation. Some of the projects are more profitable than others. Some of them were a necessity, and for some of them, Serbia had waited for more than 20 years. In the case of Železara Smederevo alone, it is obvious that the benefits are there. About 5,000 employed people and their families have income thanks to Hesteel. This company is Serbia's number one exporter, with a significant contribution to Serbian GDP. The situation is similar with ZMG Bor, which, like Železara, had many problems for several decades, and now the company is run in a better way.

For many decades, Serbian infrastructure was one of its main problems, and nowadays the situation is much better. The main problem is that Serbia will repay the loans that have been negotiated through bilateral arrangements, and not by public tenders. We cannot compare the Chinese offer to some others that may have otherwise occurred. Serbian officials state the country is dedicated to the

\footnotetext{
${ }^{11}$ Note: According to the report from Deutsche Welle in June (https://www.dw.com/en/ coronavirus-pandemic-fuels-comeback-of-cars/a-53759607), demand for used cars is increasing from May 2020, as well as demand for luxury new cars. However, the losses from January until May are huge, and it will take time for the auto industry to recover.
} 
process of joining the $\mathrm{EU}$, and one of its public business practices is the public procurement. We should be, of course, aware that tenders are not an ideal way of conducting business proposals. Even with them, we can experience many problems. Nevertheless, if we are dedicated to our EU path, we need to have those things in mind, and then the number of EU objections regarding Serbia's cooperation with China will be reduced.

From an economic point of view, it should also be noted that all infrastructural projects are done by the Chinese working force. In some cases, like in TPP Kostolac, we have Serbian companies that are working with Chinese ones, and that is a much better situation. The construction industry involved in public work is one of those which has a direct and fast impact on the development of the country. That was the reason, among others, why the USA, after the Great recession, spent so much money on public works and the construction industry.

Nevertheless, risks that Serbia is facing are also real, and among all the abovementioned two stand out. The first one is repaying the loans. Serbia has been developing thanks to FDI and reforms in monetary and fiscal policy, which resulted in a constant decrease of public debt and strengthening of the basic macroeconomic indicators. In this situation, repaying loans is not a big burden to the country. However, 2020 came, and with it, the global pandemic crisis. The economic results from all over the world are upsetting, and the same applies to Serbia. Is Serbia capable to return the loans with so many infrastructural projects, loans, and increased public debt? The answer depends on many things, and it cannot be given at this moment. But the risk is there, and it should be acknowledged.

The second risk mentioned a couple of times in this paper is air pollution. Železara Smederevo, TPP Kostolac, and Bor face the same problem. The problem did not occur due to Chinese investors, but it existed for many decades. What is worrying is that Serbia does not use all the potential of new technologies that could decrease the level of pollution, and that can help its citizens who live nearby those facilities to have a better life. Even in times like this, ecology should be one of the imperatives of our Government. If we need to have all these factories, and that is the case here, we should comply with ecological standards.

\section{CONCLUSION}

Diplomatic and economic relations between Serbia and China are constantly developing and improving. Two countries cooperate under the 16+1 and the BRI Initiatives successfully, and Serbia is among the $17+1$ countries one of those that realized numerous projects. Chinese state companies are leading the way, while 
private companies are still few and emerging. Traditional sectors are still preferential in China's allocation of investments in Serbia. It is encouraging that Serbia will have one of the biggest greenfield investments in its history from China, and this will stimulate other Chinese investors to come to the Serbian market.

The projects' dynamics are good, and except for the railway in which we had a significant delay, other projects are done according to the schedule. The BRI projects have added to Serbia's development, and both sides are further negotiating different projects in which they want to cooperate.

Financial and ecological risks are the most serious ones, while the risks of unsuccessful acquisition, unemployment, reduced export, EU regulations, COVID-19, and cross-cultural communication are those that will have an impact on the final results of the Chinese BRI investment projects in Serbia.

\section{LITERATURE}

Andrić, J.M., Wang, J.Y., Zou, P.X.W., Zhong, R.Y. (2017, November). Critical Risk Identification in One Belt-One Road Highway - Project in Serbia, CRIOCM 2017, Proceedings of 22nd International Conference on Advancement of Construction Management and Real Estate, 248-255. Melbourne, Victoria, Australia: Chinese Research Institute of Construction Management and Swinburne University of Technology

Baláž, P., Bayer J. (2018, May 17-18). Impact of China on Competitiveness of EU Steel Industry (Slovakia), Proceedings of the 4th International Conference on European Integration 2018, Technical University of Ostrava, Faculty of Economics, Department of European Integration, Ostrava, Czech Republic,188-128.

Hurley, J., Morris S. and Portelance, G. (2018, March). Examining the Debt Implications of the Belt and Road Initiative from a Policy Perspective, Center for Global Development Policy Paper 121, 1-37.

Huss W. (1988). A move towards scenario analysis, International journal of forecasting, Volume 4, Issue 3, 377-388. https://doi.org/10.1016/0169-2070(88)90105-7

Jojić, S. (2017). How Serbia perceives "The Belt and the Road" Initiative and 16+1 Cooperation, Working Paper No. 9, 1-13. Budapest, China - CEE Institute.

Lađevac, I. (April 2020). The Republic of Serbia and the Belt and Road Initiative. In A. Jović - Lazić, A. Troude (Eds.), Security challenges and the place of the Balkans and Serbia in a changing world (pp. 273- 283), Belgrade, Serbia: Institute of International Politics and Economics. 
Liu, Z. (2019). Europe and the "Belt and Road" Initiative: Responses and Risks, China -CEE Think Tanks Book Series, Beijing, China: China Social Science Press.

Obradović, Ž. (2018). "One Belt and Road" in the Balkans and in Serbia (cooperation challenges) in: V. Cvetković (Ed.), The New Silk Road: European Perspectives (Security challenges/risks within the Initiative 16+1), 187-209. University of Belgrade, Faculty of Security Studies.

Pavlićević, D. (2018). 'China Threat' and 'China Opportunity': Politics of Dreams and Fears in China-Central and Eastern European Relations, Journal of Contemporary China, vol. 27, no. 113, 688-702. https://doi.org/10.1080/ 10670564.2018.1458057

Šaranović, J., Stanojević, N., Vuletić, R., (2019). Development opportunities for growing economies on the routes of New China's Silk Road: case study of Serbia, Advances in Economics, Business and Management Research, volume 108, 5th IPMA SENET Project Management Conference (SENET 2019), 126-131, Serbia: Atlantis press.

Šekarić, N. (2020). China's 21st century geopolitics and geo-economics: An evidence from the Western Balkans. Medunarodni problemi 72, 356-376. DOI:10.2298/MEDJP2002356S.

Rogers, S. (2019). China, Hungary, and the Belgrade-Budapest Railway Upgrade: New Politically-Induced Dimensions of FDI and the Trajectory of Hungarian Economic Development, Journal of East-West Business, DOI: 10.1080/10669868.2018.1561589

Rencz, F. (2019, October). The BRI in Europe and the Budapest-Belgrade railway link, Briefing Paper, 10/2019, European Institute for Asian Studies, 1-11. Retrieved from http://www.eias.org/wp-content/uploads/2019/07/EIASBriefing-Paper-The-BRI-in-Europe-and-the-Budapest-Belgrade-RailwayLink-Final.pdf

Stanojević, N. (2019). The Impact of Chinese Infrastructure Projects on Development of Host Economies - Empirical evidence from Pakistan economy, The Review of International Affairs, Vol. LXX, No. 1173, 61-76.

Tončev, P. (2017 February). China's Road: into the Western Balkans, Brief Issue, European Union Institute for Security Studies (EUISS)

Rogelja, I., Tsimonis (2020). Narrating the China Threat: Securitising Chinese Economic Presence in Europe, The Chinese Journal of International Politics, The Institute of International Relations, Tsinghua University, 103-133, doi: 10.1093/cjip/poz019, Oxford Univeristy Press

Zakić K., Radišić, B. (2019a). Influence of the Belt and Road Initiative on Chinese Investments in Europe, Case study: Balkan Countries, in: Z. Liu, I. Lađevac 
(Eds.), The Cooperation between China and Balkan Countries under the 'Belt and Road' Initiative (pp. 27-53), Beijing, China: The Institute of European Studies (IES) Chinese Academy for Social Science.

Zakić, K., Radišić, B. (2019b). China's Belt and Road Investment Projects in the Balkan Countries: Six Years After, The Review of International Affairs, 70(1175), 48-68.

\section{Websites:}

Agencija za privredne register (2018, mart), Izveštaj o poslovanju RTB Bor d.o.o.za 2017. godinu, Retrieved from: file:///D:/chome\%20download/ Izvestaj\% 20\%20o\%20poslovanju\%20za\%202017\%20godinu\%20POTPISAN.pdf

Elektroprivreda Srbija. Istorija. Retrieved from http://www.eps.rs/lat/kostolac/ Stranice/istorija-teko.aspx

Energy Strategy of the Republic of Serbia from 2017 - 2023. Retrieved from: https://www.mre.gov.rs/doc/efikasnost-izvori/PROGRAM $\% 20$ FOR $\% 20$ THE\%20IMPLEMENTATION\%20ENERGY\%20STRATEGY\%20for $\%$ 20the $\% 20$ period $\% 20$ from $\% 202017 \% 20$ until $\% 202023$.pdf

IIPE (2018, October 26). Serbia Economy briefing: Record Breaking Month for Chinese Investments in Serbia, China - CEE Institute, Retrieved from https://china-cee.eu/2018/10/26/serbia-economy-briefing-record-breakingmonth-for-chinese-investments-in-serbia/

Janković, Popović, Mitić. JPM is advising new Chinese investor "MEI TA“, Retrieved from https://www.jpm.rs/jpm-is-advising-new-chinese-investormei-ta/

LEI.INFO. (2019, November 01), Mei Ta Industrial Co., Ltd., Retrieved from https://lei.info/254900HG35LZ644DM985

Linglong Tire. About us. Retrieved from http://www.linglongtire.com/about-us

Market Business News, What is economic risk? Definition and example, Retrieved from https://marketbusinessnews.com/financial-glossary/ economic-risk/

Ministarstvo građevinarstva, saobraćaja i infrastrukture (2019). Infrastrukturna gradilišta, Retrieved from https://www.mgsi.gov.rs/cir/infrastrukturnagradilista/modernizacija-i-rekonstrukcija-pruge-beograd-budimpeshtadeonica-beograd and https://www.mgsi.gov.rs/cir/infrastrukturna-gradilista /rekonstrukcija-i-modernizacija-deonice-stara-pazova-novi-sad-tunel

Ministarstvo privrede (2016). Kupoprodajni ugovor za određenu imovinu Železare Smederevo, Retrieved from http://www.privreda.gov.rs/wpcontent/uploads/2016/04/ASPA-FINAL-Asset-Sales-And-PurchaseAgreement-initialized_1.pdf 
Ministarstvo privrede (2019, October 10). Ugovor o dodeli sredstava Mei Ta doo, https://novaekonomija.rs/assets/documents/Mei-Ta-Ugovor-2019.pdf

Ministry of construction, transport and infrastructure, Republic of Serbia (September 2018). Serbia overview of finalized, ongoing and planned transportation and construction infrastructural projects, Retrieved from

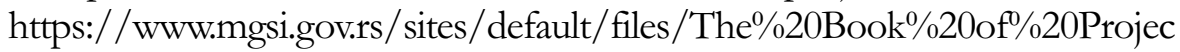
ts $\% 20-\% 20$ Ministry $\% 20$ of $\% 20$ construction $\% 2 \mathrm{C} \% 20$ transport $\% 20$ and $\%$ 20infrastructure- $\% 20$ September $\% 202018$.pdf

Ministry of construction, transport and infrastructure, Republic of Serbia (September 2019). Investment plan - Serbia, Retrieved from https://www.mgsi.gov.rs/sites/default/files/Investicioni\%20Plan\%20MGSI $\% 20$ septembar $\% 202019 \% 20$ ENG $\% 20$ tekst $\% 20$.pdf

Ministry of Foreign Affairs of the PRC (28.04.2012.). Premier Wen Jiabao Delivers a Televised Speech in Poland, Retrieved from https://www.fmprc. gov.cn/mfa_eng/wjdt_665385/zyjh_665391/t934631.shtml

Razvojna agencija Srbije (2019, July 27), Shandong Linglong" started to build tyre factory in Zrenjanin, RAS, Retrieved from: http://ras.gov.rs/shandonglinglong-started-to-build-tyre-factory-in-zrenjanin

Republic of Serbia, Ministry of Environmental Protection (2017, October 17). Decision Environmental Impact Assessment Study, Ministry of Environmental Protection RS, Retrieved from http://www.mmediu.ro/app/webroot/uploads /files/2017-10-17_Decision_Environmental_Impact_Assessement_Study.pdf

Službeni list grada Beograda 68/2020, Akcioni plan razvoja sistema daljinske energije u gradu Beogradu za period do 2025. godine sa projekcijom do 2040. godine, Retrieved from: http://demo.paragraf.rs/demo/combined/ Old/t/t2020_06/BG_068_2020_007.htm

Zijin Mining News (2019, December 04). Zijin Mining plans to acquire Columbia Gold Mine, expected to start production in the first quarter of 2020

\section{Internet sources:}

021 (2019, July 02). Građanski preokret: Kineskoj kompaniji poklonjeno zemljište u Zrenjaninu, a domaćim se naplaćuje, 021, Retrieved from https:// www.021.rs/story/Info/Vojvodina/217922/Gradjanski-preokret-Kineskojkompaniji-poklonjeno-zemljiste-u-Zrenjaninu-a-domacim-se-naplacuje.html B92, Tanjug (2008, April 08). RTB Bor: Negotiations with Russians, B92, Retrieved from https://www.b92.net/eng/news/business.php?yyyy=2008\& $\mathrm{mm}=04 \& \mathrm{dd}=11 \&$ nav_id $=49321$ 
Balkan Green Energy News (2020, June 11). Works on Chinese Linglong's tire plant complex in Serbia launched last year, but EIA is yet to be published, Balkan Green Energy News, Retrieved from https://balkangreenenergy news.com/works-on-chinese-linglongs-tire-plant-complex-in-serbialaunched-last-year-but-eia-is-yet-to-be-published/

BETA (2003, April 1).’US Steel” za 23 miliona dolara kupuje smederevski "Sartid", B92, Retrieved from https://www.b92.net/info/vesti/index.php? yyyy $=2003 \& \mathrm{~mm}=04 \& d d=01 \&$ nav_category $=9 \&$ nav_id $=104940$

BETA (2007, March 05). Vlada Srbije prodala je u ponedeljak Rudarskotopioničarski basen "Bor" kompaniji "Kuprom" (Cuprom) iz Rumunije za 400 miliona dolara, Mondo, https://mondo.rs/Info/Drustvo/a52351/ Rumuni-kupili-RTB-Bor-za-400-miliona-dolara.html

BETA (2008, February 08). Austrian A-TEC buys RTB Bor, B92, Retrieved from https:/ $/$ www.b92.net/eng/news/business.php?yyyy $=2008 \& \mathrm{~mm}=02 \& \mathrm{dd}=0$ 8\&nav_id=47554

BETA (2019). EU ustanovila kvote za uvoz čelika, tvrde da Srbiji ne prete dodatne carine, N1, http://rs.n1info.com/Biznis/a454004/EU-ustanovilakvote-za-uvoz-celika.htm

CEE Bankwatch Network. (2018, October 1). 200 million euro EBRD loan to Serbian energy giant EPS under investigation, Retrieved from https://bankwatch.org/press_release/200-million-euro-ebrd-loan-toserbian-energy-giant-eps-under-investigation

CEE Bankwatch Network. Kostolac B3 lignite power plant, Serbia, Retrieved from https://bankwatch.org/project/kostolac-lignite-power-plant-serbia

eKapija (2019, December 29). Obezbeđen kredit od 193 mil EUR za izgradnju toplodalekovoda Obrenovac-Novi Beograd - Radovi počinju na jesen 2020., ekapija, Retrieved from https:/ /www.ekapija.com/news/2736622/ obezbedjen -kredit-od-193-mil-eur-za-izgradnju-toplodalekovoda-obrenovac-novi-beograd

Kessler S. (2020, June 10). Coronavirus pandemic fuels comeback of cars, Deutche Welle, Retrieved from https://www.dw.com/en/coronaviruspandemic-fuels-comeback-of-cars/a-53759607

Obradović, M. (2019, January 24). Kvote ipak smanjuju izvoz smederevskog čelika u EU, Danas, Retrieved from https://www.danas.rs/ekonomija/kvoteipak-smanjuju-izvoz-smederevskog-celika-u-eu/

Prodanović, J. Milivojević, A. (2017, March 27). Izgradnja fabrike Mei Ta: Životna sredina u drugom planu, CINS, Retrieved from https://www.cins.rs/ izgradnja-fabrike-mei-ta-zivotna-sredina-u-drugom-planu/

SEEbiz / Tanjug (2019, July 08). Ovo su najveći srpski izvoznici, Retrieved from https://www.seebiz.eu/tvrtke/ovo-su-najveci-srpski-izvoznici/203239/ 
SEEbiz / Tanjug (2020, June 6). Brnabić: Proizvodnja Zijina u Boru udvostručena, SEEbiz, Retrieved from https://seebiz.eu/tvrtke/brnabic-proizvodnja-zijinau-boru-udvostrucena/234322

Than K., Komuves A. (2020, April 24). UPDATE 3-Hungary, China sign loan deal for Budapest-Belgrade Chinese rail project, Reuters, Retrieved from https://www.reuters.com/article/hungary-china-railway-loan/update-3hungary-china-sign-loan-deal-for-budapest-belgrade-chinese-rail-projectidUSL5N2CC6A0

Vlaović G. (2019, April 17). Investicija koja više šteti nego koristi, Danas, Retrieved from https://www.danas.rs/ekonomija/investicija-koja-vise-steti-nego-koristi/

VOICE (2019, December 04). Saobraćajna infrastruktura u Zrenjaninu teško može da podnese buduću fabriku guma, VOICE, Retrieved from https://voice.org.rs/saobracajna-infrastruktura-u-zrenjaninu-tesko-moze-dapodnese-buducu-fabriku-guma/

\section{REZULTATI I RIZICI KINESKIH POJAS I PUT INVESTICIONIH PROJEKATA U SRBIJI}

Apstrakt: Kina neprekidno od 2010. godine, povećava nivo investicionih projekata u Srbiji. Nakon pridruživanja Srbije inicijativama $17+1$ i Pojas i put, te investicije su eksponencijalno rasle. Projekti se razlikuju po veličini i sektorima u kojima se realizuju, a vodeći su infrastrukturni projekti.

Glavna svrha ovog rada je analiza postignutih rezultata kineskih investicionih projekata u Srbiji, a koji su povezani sa inicijativom Pojas i put, sa ekonomske tačke gledišta. Istovremeno, autor će predstaviti potencijalne rizike za Srbiju koji proizilaze iz tih projekata. Analizirani podaci obuhvataju period od 2014. do maja 2020. godine i prikupljeni su iz različitih izvora i vrednovani analizom sadržaja. Rizici su analizirani primenom metode scenarija. Sa empirijskog stanovišta, ovaj rad će dati novi ugao gledanja na rizike sa kojima se Srbija suočava u BRI projektima, a u svetlu promena u domaćem i međunarodnom okruženju, posebno zbog uticaja pandemije COVID-19.

Autor zaključuje da BRI projekti u Srbiji doprinose ekonomskom razvoju Srbije, ali da se Srbija istovremeno suočava sa dva glavna rizika - otplatom kredita i neusklađivanjem sa ekološkim standardima.

Ključne reči: Srbija, Kina, Inicijativa Pojas i put, investicioni projekti, ekonomski rezultati, rizik. 